\title{
Electrocardiographic Changes in Rheumatoid Arthritis
}

\section{-Supplementary Report-}

\author{
Katuyasu Asai, M.D.
}

To evaluate the significance of heart changes in rheumatoid arthritis, ST-T changes of electrocardiogram in healthy control were studied. It was significantly less frequently observed in the control group than in rheumatoid patient group.

7 HIS report deals with the incidence of electrocardiographic abnormalities 1 in the control group as compared with previously reported incidence of heart changes in rheumatoid patients. ${ }^{1,2)}$

Following results had been confirmed by the author:

Among 158 patients with rheumatoid arthritis, depression of ST segment and/or inverted or flat $\mathrm{T}$ wave were proved in 20.9 per cent (33 patients), prolonged QT ratio in 7.6, first degree A-V block in 1.3, premature beats (ventricular or supra-ventricular) in 3.8, complete right bundle branch block in 0.6 , auricular fibrillation in 0.6 , sinus tachycardia in 3.2 , and sinus bradycardia in 2.5. Age factors of the disease were not related to the incidence of electrocardiographical abnormalities. ST segment and/or T wave changes were more frequently found in the patients with high serum beta and/or gamma globulin. There were 6 autopsied cases of rheumatoid arthritis. All of them showed anatomical heart lesions.

\section{Materials and Methods}

Sex and age distributions of 158 patients with rheumatoid arthritis were described elsewhere. ${ }^{12,2)}$ The definition and classification of rheumatoid arthritis followed Steinbrocker and Ropes' criteria. ${ }^{3), 4)}$ The control group consisted of 182 healthy persons, 129 males and 53 females, whose ages ranged from 17 to 66 years. One hundred and one were apparently healthy employees of a department store in Tokyo. The blood pressure was not over 150/100 in all of them. Eighty-one were healthy volunteers including physicians, nurses and others. Among them, 102 were over 50 years of age. The average age was 41.64 . The control group is not ideally matched for their sex and age distribution to the group of rheumatoid arthritis. But as shown in Table $I$, age distribution in rheumatoid arthritis and the control group had no significant discrepancy. $\mathrm{X}^{2}=5.07<\mathrm{x}_{3}{ }^{2}(0.05)=7.81$ Twelve

From the Department of Physical Therapy and Medicine (Director ; Professor Y. Oshima) Tokyo University Hospital, Tokyo, Japan. 
Table I. Age Distribution of Rheumatoid Arthritis and Healthy Controls

\begin{tabular}{|c|c|c|c|c|c|}
\hline Age & -19 & $20-39$ & $40-59$ & $60-$ & Total \\
\hline $\begin{array}{c}\text { Number of rheumatoin } \\
\text { arthritis patients }\end{array}$ & 6 & 69 & 66 & 17 & 158 \\
\hline $\begin{array}{l}\text { Number of healthy } \\
\text { controls }\end{array}$ & 4 & 70 & 96 & 12 & 182 \\
\hline Total & 10 & 139 & 162 & 29 & 340 \\
\hline \multicolumn{5}{|c|}{$\begin{array}{l}X^{2}=5.057 \\
X_{3}^{2}=7.81(0.05)\end{array}$} & \\
\hline
\end{tabular}

leads of electrocardiogram, including 3 standard leads, 3 unipolar limb leads and 6 unipolar chest leads were taken. QT ratio was calculated in all of the control individuals. Criteria for ST-T changes in this study are:

1) horizontal or sagging depression of ST segment $0.5 \mathrm{~mm}$. or over)

2) $\frac{\mathrm{QX}}{\mathrm{QT}}>50 \%$

3) flat or diphasic $\mathrm{T}$ wave

\section{Results}

As shown in Table II the incidence of ST-T changes in the control group was significantly lower than in the group of rheumatoid arthritis at 1 per cent level. The incidence of abnormal QT ratio in the control group was higher than in the rheumatoid patient group, but not over the range of chance variation.

Bradycardia in the control group was significantly more frequently observed.

Table II. Incidence of Electrocardiographic Findings in Rheumatoid Arthritis and Healthy Control

\begin{tabular}{|c|c|c|c|c|c|c|c|c|c|c|}
\hline & $\begin{array}{l}\text { Number } \\
\text { of } \\
\text { cases }\end{array}$ & $\begin{array}{c}\text { Abnor- } \\
\text { mal } \\
\text { ST-T }\end{array}$ & $\begin{array}{c}\text { Abnor- } \\
\text { mal } \\
Q T \\
\text { ratio }\end{array}$ & $\begin{array}{c}\text { Prema } \\
\text { ture } \\
\text { beat }\end{array}$ & $\begin{array}{c}\text { First } \\
\text { degree } \\
\text { A-V } \\
\text { block }\end{array}$ & $\begin{array}{l}\text { Auricul. } \\
\text { fibrill. }\end{array}$ & $\begin{array}{l}\text { Right } \\
\text { B. B. B. }\end{array}$ & ¡W.I & $\begin{array}{l}\text { Tachy- } \\
\text { cardia }\end{array}$ & $\begin{array}{l}\text { Brady- } \\
\text { cardia }\end{array}$ \\
\hline $\begin{array}{l}\text { Rheumatoid } \\
\text { arthritis }\end{array}$ & 15 & $\begin{array}{c}33 \\
(20.9)\end{array}$ & $\begin{array}{c}12 / 91 \\
(13.2)\end{array}$ & $\begin{array}{c}6 \\
(3.8)\end{array}$ & $(1.3)$ & $(0.6)$ & $\begin{array}{c}1 \\
(0.6)\end{array}$ & 0 & $\begin{array}{c}5 \\
(3.2)\end{array}$ & $(2.4)$ \\
\hline & 6 & $\begin{array}{c}19 \\
(10.4)\end{array}$ & $\begin{array}{l}34 / 182 \\
(18.7)\end{array}$ & $\begin{array}{c}4 \\
(2.2)\end{array}$ & $\begin{array}{c}4 \\
(2.2)\end{array}$ & $(0.5)$ & $(2.2)$ & $(0.5)$ & ${ }^{3}(1.6)$ & $\begin{array}{c}53 \\
(29.1)\end{array}$ \\
\hline
\end{tabular}

(Incidence of abnormal ST-T in the group of rheumatoid arthritis is significantly high. Tachycardia is defined as over 100 heart beats per min., and bradycardia as under 60 ) 


\section{Discussion}

Cases with hypertension which is otherwise apparently a predominant factor in producing ST-T changes, were excluded from the series of this study. Subjects with diabetes mellitus, syphilis and severe anemia were also excluded. Consequently the preponderance of ST-T changes in the rheumatoid patient group appeared to be due to some " rheumatoid" origin.

Dysproteinemia can be a factor in production of the electrocardiographical abnormalities. ${ }^{11}$

Cruickshank reported that out of 100 autopsied cases of clinically active rheumatoid arthritis, there were 20 cases of arteritis which was subacute or healed form, and 10 non-specific myocarditis.5) Two out of 6 autopsied cases of the author had slight non-specific interstitial myocarditis and one had scar tissue in myocardium. ${ }^{2}$ Pathogenesis of these findings remains undetermined. ST-T changes were not found in these 3 cases.

Bradycardia in the control group was significantly more frequently observed than in the rheumatoid patient group.

\section{Summary}

The incidence of electrocardiographical abnormalities was compared between the two groups; rheumatoid arthritis and healthy control. ST-T changes of electrocardiogram were significantly less frequently observed in the control group than in rheumatoid patient group.

\section{REFERENCE}

1. Asai, K. : Geriatrics $19: 271,1964$.

2. Asai, K.: Jap. Heart J. 3 : 325, 1962.

3. Steinbrocker et al.: J. A. M. A. 140:659, 1949.

4. Ropes et al.: Bull. Rheum. Dis. 9: 175, 1958.

5. Cruickshank, B. : J. Path. Bact. 76: 223, 1958. 